\title{
Erratum to: Disease Awareness and Prevention
}

\author{
Fingani Annie Mphande
}

\section{Erratum to:}

\section{Chapter 8 in: F.A. Mphande, Infectious Diseases and Rural Livelihood in Developing Countries, DOI 10.1007/978-981-10-0428-5_8}

The book was inadvertently published with an incorrect citation on page 143, Chapter 8, section 8.7.1.7, following the line 'This project is an example of self-reliance and sustainable development in a local community', and the reference list of the chapter on page 145 the correct citation is: Ruano AL, Dahlblom K, Hurtig A, San Sebastián M (2011) "If no one else stands up, you have to"; a story of community participation and water in rural Guatemala. Global Health Action. 4(0), doi:10.3402/gha.v4i0.6412. The book, chapter, and the reference list is updated with the correction.

The updated original online version for this chapter can be found at DOI 10.1007/978-981-10-0428-5_8

\footnotetext{
F.A. Mphande ( $\square)$

Independent Consultant, Mihama-ku, Chiba-shi, Chiba, Japan

e-mail: yadoster@gmail.com

(C) Springer Science+Business Media Singapore 2016 